\title{
Improving the Engineering Students' Entrepreneurial Self-Efficacy through a Specialised Course - A Way to Improve Startup Management
}

\author{
Andrei DUMITRESCU
}

\begin{abstract}
Entrepreneurial self-efficacy is considered a reliable indicator of the entrepreneurial intentions. In order to measure the entrepreneurial self-efficacy, several scales were developed. These scales are used also to measure the efficiency of entrepreneurship study programmes, but were not used for individual courses until now. This paper presents the results of application of an entrepreneurial self-efficacy scale to measure the increase of entrepreneurial self-efficacy of engineering students after completing an entrepreneurship course in a technical university. The course lead to a significant increase of entrepreneurial self-efficacy overall, but also on all considered factors and items. It was observed a gender difference at the beginning of the course and also a gender difference in the increase of selfefficacy. An interesting finding was that for a certain factor it was noted a regress in selfefficacy for few students. Because those students thought the process was simpler than it is in reality and after acknowledging the complexity of the process, they felt unconfident.
\end{abstract}

KEYWORDS: entrepreneurial self-efficacy scale, entrepreneurship course, startup management.

\section{JEL CLASSIFICATION: I23, L26}

\section{INTRODUCTION}

Entrepreneurship is vital to the health of the economy, the well-being of society (Ma \& Tan, 2006; Shane \& Venkataraman, 2000) and the increase of life quality of all consumers. Although a startup has a relatively small turnover compared to a large company, startups, through their significant number, have an important contribution to the national budget. Then, a startup does not introduce a product or service that is used in isolation. Most of the time, the new product or service involves the emergence of new accessories or related services offered by other startups that are set up later. Thus, through a cascade effect, economic growth is stimulated. Startups need employees. Again, if one startup employs relatively few people, the share of employees in startups is high at regional or national level. By hiring people locally, startups contribute to the community development directly through the money paid to employees and indirectly through the payment of local taxes. While large industrial companies offer consumers standard products and tend to slow down technological progress for fear of financial losses, startups offer innovative products and services that are much better suited to the needs of consumers, especially those in market niches. Startups are the most conducive environment for the development of technological progress (Mortan, Ripoll, Carvalho \& Bernal, 2014). This does not mean that large companies ignore technological progress, but are more cautious and slow it down. A very important benefit brought by startups is that they create social change, respectively they bring innovation and educate the society to demand innovation.

\footnotetext{
${ }^{1}$ POLITEHNICA University of Bucharest, Romania, e-mail: andrei.dumitrescu @ upb.ro
} 
However, it should be noted for objectivity that too many startups are not beneficial. There is an optimal balance between SMEs and large companies. Startups are not as stable as a mature company and not all startups have a real chance of success. That is why there are voices that argue that the authorities should not support absolutely all startups (Shane, 2009). Then, there are areas where scientific research involves very large financial investments (extremely complex and highly specialized equipment; many researchers involved in the process, etc.) and a long period from the beginning of research to the commercial capitalization of results.

At the heart of the startup is the figure of the entrepreneur. It is not enough for someone to have an innovative idea to be an entrepreneur. That person should also have the proper attitude and the necessary skills. Professional skills, but especially transversal ones, are required at a high level during the construction of a startup. An extremely important skill is self-confidence. There are people who do not engage in entrepreneurship because they believe they lack the necessary skills (Chen, Greene \& Crick, 1998). It is important that selfconfidence is not blind, but a confidence based on a self-assessment with a high degree of objectivity. Moreover, when designing entrepreneurship programmes, universities and training companies not only transfer skills to students, but also raise the level of entrepreneurial self-efficacy (Chen, Greene \& Crick, 1998).

A few decades ago, academia became aware of the importance of the scientific approach to entrepreneurship and began to propose different approaches to studying the entrepreneur and the process of building a startup, but also to analyse the factors that influence an entrepreneur's success, entrepreneurial intentions and its level of entrepreneurial self-efficacy. Entrepreneurial-Self Efficiency (ESE) is a construct that measures individual's belief in one's ability to successfully launch a startup. In most of the variants proposed so far, entrepreneurial self-efficacy includes factors related to personal, relational and environmental characteristics. It is considered to be a strong predictor of entrepreneurial intentions.

The entrepreneurial self-efficacy scale, regardless of the variant, is the most commonly used tool for such an assessment. Not all researchers agree with the use of a specialised selfefficacy scale, but most specialists in entrepreneurship and entrepreneurship teaching advocate for entrepreneurial self-efficacy (Newman, Obschonka, Schwarz, Cohen \& Nielsen, 2019). From the very beginning Chen, Greene and Crick (1998) and others have found that there is a direct link between high entrepreneurial self-efficacy and high entrepreneurial intentions. It has also been observed that high entrepreneurial self-efficacy is directly correlated with startup's high performance, growth and innovation (Luthans, Ibrayeva, 2005; Hallak, Lindsay \& Brown, 2011; Hallak, Brown \& Lindsay, 2012; Hallak, Assaker \& Lee, 2015; McGee \& Peterson, 2017).

Table 1. Different ESE Scales

\begin{tabular}{|l|c|c|c|c|}
\hline \multicolumn{1}{|c|}{ Authors } & Year & Number of factors & Number of items & Remarks \\
\hline Chen, Greene \& Crick & 1998 & 5 & 22 & intensively used \\
\hline De Noble, Jung \& Ehrlich & 1999 & 6 & 23 & intensively used \\
\hline Zhao, Seibert \& Hills & 2005 & 1 & 4 & \\
\hline Barbosa, Gerhardt \& Kickul & 2007 & 4 & 18 & \\
\hline $\begin{array}{l}\text { McGee, Peterson, } \\
\text { Mueller \& Sequeira }\end{array}$ & 2009 & 5 & 19 & \\
\hline Moberg & 2013 & 5 & 22 & neutral wording \\
\hline $\begin{array}{l}\text { Barakat, Boddington } \\
\text { \& Vyakarnam }\end{array}$ & 2014 & 7 & 7 & \\
\hline Schjoedt \& Craig & 2017 & 1 & 3 & $\begin{array}{l}\text { based on nascent } \\
\text { entrepreneurs }\end{array}$ \\
\hline
\end{tabular}

Source: adapted from Newman, Obschonka, Schwarz, Cohen \& Nielsen (2019) 
Over time, researchers have proposed several scales for assessing entrepreneurial self-efficacy (some of which are presented in Table 1). The differences are notable both in the number of items (some being complex, others very simple), and in the nature of the analysed factors. Of the ESE scales indicated, the most frequently used were those proposed in 1998 and 1999, because to their complexity and the coverage of all relevant factors.

Based on the proposed constructs, the past research analysed different factors that can influence the entrepreneurial self-efficacy and found that these factors were significant:

- work experience;

- education and training in entrepreneurship;

- entrepreneur's individual characteristics (gender; emotional intelligence; risk propensity; counterfactual thinking; cognitive style).

Work experience is very useful for the future entrepreneur, especially if she/he has worked in the field, gaining specialized knowledge. The fact that the entrepreneur occupied a leadership position contributes to increasing confidence in her/his leadership qualities. But any work experience in general is beneficial for the entrepreneur (Farashah, 2015; Pfeifer, Šarlija \& Sušac, 2016; Hockerts, 2017).

Before widely inaugurating new entrepreneurship curricula, universities and other educational organisations have studied the impact of participation in entrepreneurial education and training programmes on students' entrepreneurial self-efficacy. Not only educational and training organisations have approached this direction, but also unaffiliated researchers. There have been many research results that have shown a strong and positive correlation between studying entrepreneurship in an organized setting and the level of entrepreneurial self-efficacy (Zhao, Seibert \& Hills, 2005; Wilson, Kickul \& Marlino, 2007; Karlsson \& Moberg, 2013; Kubberød \& Pettersen, 2017; Gielnik, Uy, Funken \& Bischoff, 2017; Nowiński, Haddoud, Lančarič, Egerová \& Czeglédi, 2017).

Entrepreneur's individual characteristics were subject to researchers' attention and several characteristics were envisaged. Age proved to be not significant (Ayodele, 2013). There were carried-out a lot of research on the gender issue. Most of researchers found that females on average have lower levels of ESE than males (Zhao, Seibert \& Hills, 2005; Wilson, Kickul \& Marlino, 2007; Harris \& Gibson, 2008; Wilson, Kickul, Marlino, Barbosa \& Griffiths, 2009; Díaz-García \& Jiménez-Moreno, 2010; Wennberg, Pathak \& Autio, 2013; Dempsey \& Jennings, 2014). But others evidence indicated the opposite (Ayodele, 2013; Coleman \& Kariv, 2014), even no gender differences (Zhao, Seibert \& Hills, 2005; Mueller \& Dato-On, 2008).

Entrepreneurial self-efficacy is positively influenced by emotional intelligence (Salvador, 2008; Mortan, Ripoll, Carvalho \& Bernal, 2014) and risk propensity (Zhao, Seibert \& Hills, 2005), but negatively related to counterfactual thinking (Arora, Haynie \& Laurence, 2013).

Cognitive style has proven to be a subtle feature, respectively cognitive style influences differently the components of entrepreneurial self-efficacy. Thus, people with an intuitive cognitive style are confident in their ability to identify business opportunities, but are not so confident in their ability to manage resources and relate to employees, investors, etc. And analytical persons are confident in planning and using resources, but they think they have trouble in the identification of business opportunities (Barbosa, Gerhardt \& Kickul, 2007; Kickul, Gundry, Barbosa \& Whitcanack, 2009).

\section{RESEARCH OBJECTIVES}

It was expected and researches (Wilson, Kickul \& Marlino, 2007; Von Graevenitz, Harhoff \& Weber, 2010; Karlsson \& Moberg, 2013) confirmed that studies increase students' entrepreneurial self-efficacy, but high entrepreneurial self-efficacy has also been found to 
influence learning behaviour (Chou, Shen \& Hsiao, 2011). The classic approach in evaluating entrepreneurial self-efficacy is the application of pre- and post-programme surveys (Von Graevenitz, Harhoff \& Weber, 2010; Karlsson \& Moberg, 2013).

Piperopoulos \& Dimov (2015) diversified the research of the efficiency of university programmes in increasing entrepreneurial self-efficacy, respectively they analysed separately the theoretically-oriented programmes and the practically-oriented programmes. They found that higher self-efficacy is associated with lower entrepreneurial intentions in the theoretically-oriented courses, and with higher entrepreneurial intentions in the practicallyoriented courses.

The vast majority of research has focused on entrepreneurship programmes and not individual entrepreneurship courses existing in different programmes. Thus, the objective of this research was to analyse the effectiveness of an entrepreneurship course taught at a technical university in increasing entrepreneurial self-efficacy. The influence of the course on the level of some factors in entrepreneurial self-efficacy was also studied. The research results will be used to improve the course.

\section{PRESENTATION OF THE ENTREPRENEURSHIP COURSE}

Entrepreneurship education has a triple role: a) it creates student awareness related to the possibility of starting her/his own business; b) endows the student with the knowledge and skills necessary to start a business; and c) increases the student's self-confidence, determining the intensification of entrepreneurial intentions. The influence of formal entrepreneurship education increases entrepreneurial self-efficacy (Zhao, Seibert \& Hills, 2005). Therefore, in recent decades, more and more universities have included entrepreneurship courses in their curricula (Kuratko, 2005).

Entrepreneurs can emerge from any professional category, not only from the economic and management fields. For the industrial companies, it is advisable that most entrepreneurs to be engineers, because engineers can understand and solve efficiently technical problems and, especially, their knowledge in the field allow them to be innovative easily. But the structure and emphasis of the courses differ, taking into account the needs and the general set of knowledge of the respective students (Kingon, Markham, Thomas \& Debo, 2002).

Therefore, the discipline Entrepreneurship and Business Development was introduced in the curricula of two master programmes in the fields of Engineering and Management and, respectively, Industrial Engineering, at an important technical university in Romania. It should be noted that, like those observed by Kingon, Markham, Thomas \& Debo (2002) in American universities, these study programmes have in the core area the New Product Development course. In fact, students complete the two programmes with an individual dissertation, but which reflects the development of a new product, carried out in a team.

As some researchers (Piperopoulos \& Dimov, 2015) have found that the level of entrepreneurial self-efficacy depends on the content of the course, below it is presented the course content, noting that the vast majority of subchapters include short case studies:

1. transversal profile and the mode of action of the entrepreneur;

2. identifying opportunities and generating business ideas;

3. consulting specialists in taxation and law;

4. methods related to the development of a startup (Lean Startup; Design Thinking);

5. resource planning (human resource, financial resource, etc.);

6. business development (internal and external growth resources);

7. ending a business;

8. ethics and social responsibility in business;

9. recommendations for the entrepreneur. 
To consolidate the practical aspects of entrepreneurship, the course is associated with a project in which students take the first steps in developing a new business based on an idea proposed by them and approved by the teacher. The main stages of the project are: 1) primary analysis of the business idea; 2) establishing the legal form of organisation of the company; 3) competition analysis; 4) testing the market interest for the new product / service; 5) study of the legislation, standards and patents related to the new product / service; 6) drafting the business model (according to a given structure); 7) elaboration of the value proposition; 8) resource planning (human, financial, etc.); 9) promoting the new product / service.

The course taught to students did not contain in-depth theoretical aspects, such as the construct of the various elements related to entrepreneurship. The entrepreneurial self-efficacy scale was not explained either, only the experiment's objective was explained to the students. The project was not intended to assist students in building a startup, because it included only the first stages of starting a business. Therefore, it can be considered that the whole discipline was equally balanced between theory and practice.

\section{DESIGN OF EXPERIMENT}

The first decision regarding the design of the experiment was related to the entrepreneurial self-efficacy scale to be used. The idea of creating a new entrepreneurial self-efficacy scale was considered, but the following issues were immediately identified: a) it would have been just another scale that would have increased unnecessarily the number of existing ones; b) there was a danger that the design of the scale will be biased by the structure of the course, respectively the new scale will have been designed so that the course will obtain high scores. In conclusion, the idea of designing of a new scale was abandoned and the identification of the most appropriate scale was pursuit.

In order to choose a scale from the scientific literature, a construct of factors was set as selection criteria. These factors should be critical for the success of the entrepreneur. The considered factors were: a) ability to develop a new product / service; b) identification of market opportunities; c) capacity to synthesise the very basic aim of the startup; d) ability to obtain funds from investors; e) ability to select and lead human resources; f) capacity to foster innovation; g) mastership in solving unexpected situations. All scales found in the literature were analysed against these criteria and the scale proposed by De Noble, Jung, and Ehrlich (1999) emerged as superior and it was selected.

Then, both the construct's factors and the items were analysed in-depth and it was concluded that they served the purpose of the research very well and no change was needed. The chosen questionnaire was translated into Romanian. A 7-level Likert scale was used. In the entrepreneurial self-efficacy assessment questionnaire, the items were shuffled, so that students cannot realize the real structure of the construct and their answers cannot be biased. (The questionnaire items appear in the table of the next chapter.)

\section{EXPERIMENTAL RESULTS}

The two entrepreneurial self-efficacy questionnaires (pre- and post- course) were filled by 103 students (49 women and 54 men). In fact, more students were involved, but the questionnaires of students who filled only one questionnaire were not taken into account. Some of the students who filled the questionnaires had already started a business, and others were involved in developing or running a family business.

The first set of questionnaires was completed at the beginning of the course, in October, and the second set after the end of the course, in January the following year, just before the exam 
session. The questionnaires were filled online during the students' free time. (Note that not all the students participating in the experiment passed the discipline in the first exam session).

The $\mathrm{Z}$ score was calculated for each participant and it varied between -1.24 and +2.29 , so no participant input was necessary to be removed. The reliability of the two phases of the experiment was tested using Cronbach's alpha coefficient. Because the Cronbach's alpha values were quite consistent $\alpha_{1}=0.95$ and $\alpha_{2}=0.95$, the results were validated.

The results of the experiment are displayed in Table 2 . The variance of results ranged from 1.17 to 2.22 (Test 1) and from 0.63 to 1.68 (test 2). It can be observed that the variance narrowed in the second test.

Table 2. Experimental results (Means)

\begin{tabular}{|c|c|c|c|c|c|c|c|c|c|}
\hline & \multicolumn{3}{|c|}{ Test 1} & \multicolumn{3}{|c|}{ Test 2} & \multicolumn{3}{|c|}{ Difference } \\
\hline & $\mathbf{F}$ & M & $\mathbf{T}$ & $\mathbf{F}$ & $\mathbf{M}$ & $\mathbf{T}$ & $\mathbf{F}$ & $\mathbf{M}$ & $\mathbf{T}$ \\
\hline \multicolumn{10}{|c|}{ Developing new product and market opportunities } \\
\hline $\begin{array}{l}\text { I can see new market opportunities } \\
\text { for new products and services. }\end{array}$ & 5.35 & 5.15 & 5.24 & 5.65 & 5.87 & 5.77 & 0.31 & 0.72 & 0.52 \\
\hline $\begin{array}{l}\text { I can discover new ways to improve } \\
\text { existing products. }\end{array}$ & 5.04 & 5.69 & 5.38 & 5.92 & 5.83 & 5.87 & 0.88 & 0.15 & 0.50 \\
\hline $\begin{array}{l}\text { I can identify new areas for potential } \\
\text { growth. }\end{array}$ & 4.53 & 4.76 & 4.65 & 5.92 & 5.28 & 5.58 & 1.39 & 0.52 & 0.93 \\
\hline $\begin{array}{l}\text { I can design products that solve } \\
\text { current problems. }\end{array}$ & 5.16 & 5.69 & 5.44 & 5.53 & 6.06 & 5.81 & 0.37 & 0.37 & 0.37 \\
\hline $\begin{array}{l}\text { I can create products that fulfil } \\
\text { customers' unmet needs. }\end{array}$ & 5.08 & 5.65 & 5.38 & 5.71 & 6.09 & 5.91 & 0.63 & 0.44 & 0.53 \\
\hline $\begin{array}{l}\text { I can bring product concepts to market } \\
\text { in a timely manner. }\end{array}$ & 4.59 & 5.11 & 4.86 & 5.49 & 5.31 & 5.40 & 0.90 & 0.20 & 0.53 \\
\hline $\begin{array}{l}\text { I can determine what the business will } \\
\text { look like. }\end{array}$ & 5.37 & 5.35 & 5.36 & 6.06 & 5.74 & 5.89 & 0.69 & 0.39 & 0.53 \\
\hline \multicolumn{10}{|l|}{ Building an innovative environment } \\
\hline $\begin{array}{l}\text { I can create a working environment } \\
\text { that lets people be more their own } \\
\text { boss. }\end{array}$ & 5.86 & 5.26 & 5.54 & 6.12 & 5.72 & 5.91 & 0.27 & 0.46 & 0.37 \\
\hline $\begin{array}{l}\text { I can develop a working environment } \\
\text { that encourages people to try out } \\
\text { something new. }\end{array}$ & 5.12 & 5.48 & 5.31 & 5.67 & 5.74 & 5.71 & 0.55 & 0.26 & 0.40 \\
\hline $\begin{array}{l}\text { I can encourage people to take } \\
\text { initiatives and responsibilities for their } \\
\text { ideas and decisions. }\end{array}$ & 5.24 & 5.33 & 5.29 & 6.14 & 5.69 & 5.90 & 0.90 & 0.35 & 0.61 \\
\hline $\begin{array}{l}\text { I can form partner or alliance } \\
\text { relationship with others. }\end{array}$ & 6.00 & 6.30 & 6.16 & 6.22 & 6.50 & 6.37 & 0.22 & 0.20 & 0.21 \\
\hline \multicolumn{10}{|l|}{ Initiating investor relationships } \\
\hline $\begin{array}{l}\text { I can develop and maintain favourable } \\
\text { relationships with potential investors. }\end{array}$ & 5.76 & 5.26 & 5.50 & 5.86 & 5.65 & 5.75 & 0.10 & 0.39 & 0.25 \\
\hline $\begin{array}{l}\text { I can develop relationships with key } \\
\text { people who are connected to capital } \\
\text { sources. }\end{array}$ & 5.63 & 5.43 & 5.52 & 6.10 & 5.61 & 5.84 & 0.47 & 0.19 & 0.32 \\
\hline
\end{tabular}




\begin{tabular}{|c|c|c|c|c|c|c|c|c|c|}
\hline & \multicolumn{3}{|c|}{ Test 1} & \multicolumn{3}{|c|}{ Test 2} & \multicolumn{3}{|c|}{ Difference } \\
\hline & $\mathbf{F}$ & $\mathbf{M}$ & $\mathbf{T}$ & $\mathbf{F}$ & $\mathbf{M}$ & $\mathbf{T}$ & $\mathbf{F}$ & $\mathbf{M}$ & $\mathbf{T}$ \\
\hline $\begin{array}{l}\text { I can identify potential sources } \\
\text { of funding for investment. }\end{array}$ & 5.14 & 5.30 & 5.22 & 5.69 & 5.44 & 5.56 & 0.55 & 0.15 & 0.34 \\
\hline \multicolumn{10}{|l|}{ Defining core purpose } \\
\hline $\begin{array}{l}\text { I can articulate vision and values } \\
\text { of the organization. }\end{array}$ & 5.43 & 5.48 & 5.46 & 5.84 & 5.72 & 5.78 & 0.41 & 0.24 & 0.32 \\
\hline $\begin{array}{l}\text { I can inspire others to embrace vision } \\
\text { and values of the company. }\end{array}$ & 5.61 & 5.35 & 5.48 & 5.86 & 5.74 & 5.80 & 0.24 & 0.39 & 0.32 \\
\hline $\begin{array}{l}\text { I can formulate a set of actions } \\
\text { in pursuit of opportunities. }\end{array}$ & 5.12 & 5.30 & 5.21 & 5.82 & 5.78 & 5.80 & 0.69 & 0.48 & 0.58 \\
\hline \multicolumn{10}{|l|}{ Coping with unexpected challenges } \\
\hline $\begin{array}{l}\text { I can work productively under } \\
\text { continuous stress. pressure and } \\
\text { conflict. }\end{array}$ & 5.55 & 5.74 & 5.65 & 5.90 & 5.98 & 5.94 & 0.35 & 0.24 & 0.29 \\
\hline $\begin{array}{l}\text { I can tolerate unexpected changes } \\
\text { in business conditions. }\end{array}$ & 4.43 & 5.13 & 4.80 & 5.12 & 5.89 & 5.52 & 0.69 & 0.76 & 0.73 \\
\hline I can persist in the face of adversity. & 5.18 & 5.06 & 5.12 & 5.84 & 5.63 & 5.73 & 0.65 & 0.57 & 0.61 \\
\hline \multicolumn{10}{|l|}{ Developing critical human resources } \\
\hline I can recruit and train key employees. & 5.14 & 4.87 & 5.00 & 5.67 & 5.30 & 5.48 & 0.53 & 0.43 & 0.48 \\
\hline $\begin{array}{l}\text { I can develop contingency plans to } \\
\text { backfill key technical staff. }\end{array}$ & 5.10 & 5.20 & 5.16 & 5.73 & 5.65 & 5.69 & 0.63 & 0.44 & 0.53 \\
\hline $\begin{array}{l}\text { I can identify and build management } \\
\text { teams. }\end{array}$ & 5.04 & 5.22 & 5.14 & 5.29 & 5.39 & 5.34 & 0.24 & 0.17 & 0.20 \\
\hline Mean & 5.24 & 5.35 & 5.30 & 5.79 & 5.72 & 5.75 & 0.55 & 0.37 & 0.46 \\
\hline
\end{tabular}

The increase in the entrepreneurial self-efficacy level was not spectacular, because the level was high from the beginning: 5.3 (5.24 for female participants and 5.35 for male participants). After completing the course, the entrepreneurial self-efficacy level was, on average, 5.75 (5.79 for female participants and 5.72 for male participants). There was a general increase of the level (as discovered by Zhao, Seibert, \& Hills in 2005), but also an increase differentiated on gender. But the increase in the level of entrepreneurial self-efficacy is more spectacular for women, which confirms the findings of Wilson, Kickul \& Marlino (2007), after the experiment organized with MBA students.

The differences between the post- and pre-course levels were calculated for each participant. The increase in the entrepreneurial self-efficacy level was calculated as the sum of the postand pre-course differences. The increase was on average 10.5 per participant (maximum 36; minimum 1). The highest increase in the entrepreneurial self-efficacy level per item was +4 , and the lowest was -1 .

Then, the results were analysed by factors. In particular, the level reached (final average of all items) and the difference between post- and pre-course averages was studied. The best result was obtained for the factor "Building an innovative environment" with a final average (postcourse) of 5.97 (of max. 7) and a difference of 0.4 between post- and pre-course averages. Very good results were also obtained for the factors: "Developing new product and market opportunities" - final average of 5.75 and a difference of 0.56 ; and "Coping with unexpected 
challenges" - final average of 5.73 and a difference of 0.54 . The lowest values were obtained for the factor "Developing critical human resources" - average of 5.5 and a difference of 0.4 . As some students experienced a decrease in the level of entrepreneurial self-efficacy in staff recruitment, they were subsequently contacted through various channels and asked about this aspect. Some of those surveyed were surprised that they scored lower on the post-course test, but most said that they initially thought things were simple in terms of human resources: they hired a few friends and some reliable people.

An important mention to make is that the Entrepreneurship and Business Development is a compulsory course, so there are no students from the considered master programmes that do not follow this course. In this situation, it is impossible to make a control group and subsequently the set of available statistical methods narrowed considerably.

However, another statistical method was employed to substantiate the increase in entrepreneurship self-efficacy. The method was the T-Test - Paired Two Sample for Means. The null hypothesis was: "The entrepreneurial self-efficacy increased after the completion of the course". The T-Test was applied for each item of the scale. It was noted that for item "I can see new market opportunities for new products and services" there was a significant difference in the scores for pre-course test $(M=5.24, S D=1.09)$ and post-course test $(\mathrm{M}=5.77, S D=0.93), t(102)=-6.63, p=8.12 \times 10^{-10}$. The results of all T-Tests are displayed in Table 3. It can be easily observed that the students' progress is significant for all items.

Table 3. Results of T-Test - Paired Two Sample for Means

\begin{tabular}{|c|c|c|c|}
\hline & $t(\mathbf{1 0 2})$ & $p<0.05$ & Difference is \\
\hline \multicolumn{4}{|l|}{ Developing new product and market opportunities } \\
\hline $\begin{array}{l}\text { I can see new market opportunities for new products } \\
\text { and services. }\end{array}$ & -6.63 & $8.12 \times 10^{-10}$ & significant \\
\hline $\begin{array}{l}\text { I can discover new ways to improve existing } \\
\text { products. }\end{array}$ & -5.24 & $4.3 \times 10^{-7}$ & significant \\
\hline I can identify new areas for potential growth. & -9.93 & $1.2 \times 10^{-10}$ & significant \\
\hline I can design products that solve current problems. & -5.57 & $1.3 \times 10^{-7}$ & significant \\
\hline $\begin{array}{l}\text { I can create products that fulfil customers' unmet } \\
\text { needs. }\end{array}$ & -7.09 & $9 \times 10^{-11}$ & significant \\
\hline $\begin{array}{l}\text { I can bring product concepts to market in a timely } \\
\text { manner. }\end{array}$ & -6.21 & $5.2 \times 10^{-9}$ & significant \\
\hline I can determine what the business will look like. & -6.86 & $2.7 \times 10^{-10}$ & significant \\
\hline \multicolumn{4}{|l|}{ Building an innovative environment } \\
\hline $\begin{array}{l}\text { I can create a working environment that lets people be } \\
\text { more their own boss. }\end{array}$ & -5.35 & $2.7 \times 10^{-7}$ & significant \\
\hline $\begin{array}{l}\text { I can develop a working environment that encourages } \\
\text { people to try out something new. }\end{array}$ & -5.62 & $8.3 \times 10^{-8}$ & significant \\
\hline $\begin{array}{l}\text { I can encourage people to take initiatives and } \\
\text { responsibilities for their ideas and decisions. }\end{array}$ & -6.74 & $4.7 \times 10^{-10}$ & significant \\
\hline I can form partner or alliance relationship with others. & -3.68 & $1.84 \times 10^{-4}$ & significant \\
\hline
\end{tabular}




\begin{tabular}{|c|c|c|c|}
\hline & $t(\mathbf{1 0 2})$ & $p<0.05$ & Difference is \\
\hline \multicolumn{4}{|l|}{ Initiating investor relationships } \\
\hline $\begin{array}{l}\text { I can develop and maintain favourable relationships } \\
\text { with potential investors. }\end{array}$ & -3.3 & $6.64 \times 10^{-4}$ & significant \\
\hline $\begin{array}{l}\text { I can develop relationships with key people who are } \\
\text { connected to capital sources. }\end{array}$ & -4.22 & $2.6 \times 10^{-5}$ & significant \\
\hline $\begin{array}{l}\text { I can identify potential sources of funding for } \\
\text { investment. }\end{array}$ & -4.97 & $1.3 \times 10^{-6}$ & significant \\
\hline \multicolumn{4}{|l|}{ Defining core purpose } \\
\hline I can articulate vision and values of the organization. & -4.53 & $78 \times 10^{-6}$ & significant \\
\hline $\begin{array}{l}\text { I can inspire others to embrace vision and values of } \\
\text { the company. }\end{array}$ & -4.82 & $2.5 \times 10^{-6}$ & significant \\
\hline $\begin{array}{l}\text { I can formulate a set of actions in pursuit of } \\
\text { opportunities. }\end{array}$ & -8.89 & $1.12 \times 10^{-14}$ & significant \\
\hline \multicolumn{4}{|l|}{ Coping with unexpected challenges } \\
\hline $\begin{array}{l}\text { I can work productively under continuous stress. } \\
\text { pressure and conflict. }\end{array}$ & -4.09 & $4.3 \times 10^{-5}$ & significant \\
\hline $\begin{array}{l}\text { I can tolerate unexpected changes in business } \\
\text { conditions. }\end{array}$ & -9.02 & $5 \times 10^{-15}$ & significant \\
\hline I can persist in the face of adversity. & -6.52 & $1.3 \times 10^{-9}$ & significant \\
\hline \multicolumn{4}{|l|}{ Developing critical human resources } \\
\hline I can recruit and train key employees. & -4.65 & $4.8 \times 10^{-6}$ & significant \\
\hline $\begin{array}{l}\text { I can develop contingency plans to backfill key } \\
\text { technical staff. }\end{array}$ & -5.48 & $1.5 \times 10^{-7}$ & significant \\
\hline I can identify and build management teams. & -3.12 & $\underset{3}{1.157 \times 10^{-}}$ & significant \\
\hline
\end{tabular}

Because there were few students who already had a business or worked for the family's business, it was not possible to perform a statistical analysis on the difference between the entrepreneurial self-efficacy of regular students and that of those who were already entrepreneurs. The qualitative observations did not reveal notable differences between the entrepreneurial self-efficacy levels of the two categories of students.

The syllabi of the master programmes were studied to find out which other courses could improve the self-efficacy. Most of the courses (like Advanced Manufacturing Processes, Mathematical Methods in Engineering etc.) were dismissed and remained only Product Development. It should be noted that it was not possible to investigate the extent to which the increase in entrepreneurial self-efficacy level on the factor "Developing new product and market opportunities" is the result of the contribution of the Entrepreneurship and Business Development course, differentiated from the Product Development course. However, it can be considered acceptable that both courses have a contribution in this direction.

It can be reckoned that the course Entrepreneurship and Business Development is efficient and well designed. The aspects related to human resources management will be improved in the direction of presenting more case studies and recommendations so that students become more confident in their own knowledge and skills. 


\section{CONCLUSIONS}

The entrepreneurial self-efficacy scale used (De Noble, Jung, \& Ehrlich) was useful and efficient. Because the scale was clear and precise, the students had no doubts when completing the questionnaires, nor did they have any subsequent complaints. The results obtained were quite reliable, the Cronbach alpha coefficient being 0.95 in both tests. It can be appreciated that a specialised scale is effective in assessing the entrepreneurial self-efficacy. After the pre- and post-course testing, an increase of the entrepreneurial self-efficacy level was observed on all items, indicating objectively the efficiency of the entrepreneurship course. Similar results have been obtained by Zhao, Seibert \& Hills (2005), Wilson, Kickul \& Marlino (2007), Von Graevenitz, Harhoff \& Weber (2010), Karlsson \& Moberg (2013). Because the course was assessed as being balanced between theoretical and practical, it was not possible to verify the findings of Piperopoulos \& Dimov (2015).

The results of the first test indicated that female students had an entrepreneurial self-efficacy slightly lower than male students, in line with those found by other researchers (Zhao, Seibert \& Hills, 2005; Harris \& Gibson, 2008; Wilson, Kickul, Marlino, Barbosa \& Griffiths, 2009; Díaz-García \& Jiménez-Moreno, 2010; Dempsey \& Jennings, 2014). However, the increase in entrepreneurial self-efficacy after the course was more pronounced for female students ( 0.55 versus 0.37 on a Likert scale of 7 ), similar to that found by Wilson, Kickul \& Marlino (2007). In summary, entrepreneurial self-efficacy is gender dependent.

The experiment also leads to some surprising results, namely a decline in the confidence of some students regarding the factor of recruitment of human resources. Because the initial impression of those students was that the recruitment of human resources is simple and straightforward, the awareness of the complexity and importance of the process puzzled them. A similar situation was observed by Von Graevenitz, Harhoff \& Weber (2010).

It was noted that another course in the study programme could contribute to the growth of one factor of the entrepreneurial self-efficacy. Therefore, when it comes to a course in a programme, the specific contribution of the course should be pursuit, especially when the entrepreneurial self-efficacy factors are under the influence of several courses. There are two ways to record the specific contribution of a course: a) some items are modified, so that they refer very clearly to the issues addressed in the course; b) by indicating at the beginning of the questionnaire that the student should think only at the course in question.

\section{REFERENCES}

Arora, P., Haynie, J. M. \& Laurence, G. A. (2013). Counterfactual thinking and entrepreneurial self-efficacy: The moderating role of self - esteem and dispositional affect. Entrepreneurship Theory and Practice, 37(2), 359-385.

Ayodele, K. O. (2013). Demographics, entrepreneurial self-efficacy and locus of control as determinants of adolescents' entrepreneurial intention in Ogun state, Nigeria. European Journal of Business and Social Sciences, 1(12), 59-67.

Barbosa, S. D., Gerhardt, M. W. \& Kickul, J. R. (2007). The role of cognitive style and risk preference on entrepreneurial self-efficacy and entrepreneurial intentions. Journal of Leadership \& Organizational Studies, 13(4), 86-104.

Chen, C. C., Greene, P. G. \& Crick, A. (1998). Does entrepreneurial self-efficacy distinguish entrepreneurs from managers? Journal of business venturing, 13(4), 295-316. 
Chou, C. M., Shen, C. H. \& Hsiao, H. C. (2011). The influence of entrepreneurial selfefficacy on entrepreneurial learning behavior-using entrepreneurial intention as the mediator variable. International Business and Management, 3(2), 7-11.

Coleman, S. \& Kariv, D. (2014). 'Deconstructing' entrepreneurial self-efficacy: A gendered perspective on the impact of ESE and community entrepreneurial culture on the financial strategies and performance of new firms. Venture Capital, 16, 157-181.

De Noble, A. F., Jung, D. \& Ehrlich, S. B. (1999). Entrepreneurial self-efficacy: The development of a measure and its relationship to entrepreneurial action. Frontiers of entrepreneurship research, 1999, (1), 73-87.

Dempsey, D. \& Jennings, J. (2014). Gender and entrepreneurial self-efficacy: A learning perspective. International Journal of Gender and Entrepreneurship, 6(1), 28-49.

Díaz-García, M. \& Jiménez-Moreno, J. (2010). Entrepreneurial intention: The role of gender. International Entrepreneurship and Management Journal, 6(3), 261-283.

Farashah, A. (2015). The effects of demographic, cognitive and institutional factors on development of entrepreneurial intention: Toward a socio-cognitive model of entrepreneurial career. Journal of International Entrepreneurship, 13, 452-476.

Gielnik, M., Uy, M. A., Funken, R. \& Bischoff, K. M. (2017). Boosting and sustaining passion: A long-term perspective on the effects of entrepreneurship training. Journal of Business Venturing, 32, 334-353.

Hallak, R., Assaker, G. \& Lee, C. (2015). Tourism entrepreneurship performance: The effects of place identity, self-efficacy, and gender. Journal of Travel Research, 54(1), 36-51.

Hallak, R., Brown, G. \& Lindsay, N. (2012). The place identity - Performance relationship among tourism entrepreneurs: A structural equation modelling analysis. Tourism Management, 33, 143-154.

Hallak, R., Lindsay, N. \& Brown, G. (2011). Examining the role of entrepreneurial experience and entrepreneurial self-efficacy on SMTE performance. Tourism Analysis, 16, 583-599.

Harris, M. and Gibson, S. (2008), Examining the entrepreneurial attitudes of US business students, Education and Training, 50(7), 568-581.

Hockerts, K. (2017). Determinants of social entrepreneurial intentions. Entrepreneurship: Theory and Practice, 41(1), 105-130.

Karlsson, T. \& Moberg, K. (2013). Improving perceived entrepreneurial abilities through education: Exploratory testing of an entrepreneurial self efficacy scale in a pre-post setting. The International Journal of Management Education, 11(1), 1-11.

Kickul, J., Gundry, L. K., Barbosa, S. D. \& Whitcanack, L. (2009). Intuition versus analysis? Testing differential models of cognitive style on entrepreneurial self-efficacy and the new venture creation process. Entrepreneurship Theory and Practice, 33(2), 439-453.

Kingon, A. I., Markham, S., Thomas, R. \& Debo, R. (2002). Teaching high-tech entrepreneurship: Does it differ from teaching entrepreneurship? (And does it matter?). In Proceedings of the 2002 American Society for Engineering Education Annual Conference \& Exposition, 1-13.

Kubberød, E. \& Pettersen, I. B. (2017). Exploring situated ambiguity in students' entrepreneurial learning. Education and Training, 59(3), 265-279. 
Kuratko, D. F. (2005). The emergence of entrepreneurship education: Development, trends, and challenges. Entrepreneurship Theory and Practice, 29(5), 577-597.

Luthans, F. \& Ibrayeva, E. S. (2006). Entrepreneurial self-efficacy in Central Asian transition economies: quantitative and qualitative analyses. Journal of International Business Studies, 37(1), 92-110.

Ma, H. \& Tan, J. (2006). Key components and implications of entrepreneurship: A 4-P framework. Journal of Business Venturing, 21(5), 704-725.

McGee, J. E., Peterson, M., Mueller, S. L. \& Sequeira, J. M. (2009). Entrepreneurial self-efficacy: refining measure. Entrepreneurship Theory and Practice, 33(4), 965-988.

McGee, J. \& Peterson, M. (2017). The long-term impact of entrepreneurial self-efficacy and entrepreneurial orientation on venture performance. Journal of Small Business Management. http://dx.doi.org/10.1111/jsbm.12324

Moberg, K. (2013). An entrepreneurial self-efficacy scale with a neutral wording. In Alain Fayolle, Paula Kyrö, Tonis Mets, Urve Venesaar (Eds.), Conceptual Richness and Methodological Diversity in Entrepreneurship Research, Cheltenham: Edward Elgar.

Mortan, R. A., Ripoll, P., Carvalho, C. \& Bernal, M. C. (2014). Effects of emotional intelligence on entrepreneurial intention and self-efficacy. Revista de Psicología del Trabajo y de las Organizaciones, 30(3), 97-104.

Mueller, S. L. \& Dato-On, M. C. (2008). Gender-role orientation as a determinant of entrepreneurial self-efficacy. Journal of Developmental Entrepreneurship, 13(1), 3-20.

Newman, A., Obschonka, M., Schwarz, S., Cohen, M. \& Nielsen, I. (2019). Entrepreneurial self-efficacy: A systematic review of the literature on its theoretical foundations, measurement, antecedents, and outcomes, and an agenda for future research. Journal of Vocational Behavior, 110, 403-419.

Nowiński, W., Haddoud, M. Y., Lančarič, D., Egerová, D. \& Czeglédi, C. (2017). The impact of entrepreneurship education, entrepreneurial self-efficacy and gender on entrepreneurial intentions of university students in the Visegrad countries. Studies in Higher Education. http://dx.doi.org/10.1080/03075079.2017.1365359.

Pfeifer, S., Šarlija, N. \& Zekic Sušac, M. (2016). Shaping the entrepreneurial mindset: Entrepreneurial intentions of business students in Croatia. Journal of Small Business Management, 54, 102-117.

Piperopoulos, P. \& Dimov, D. (2015). Burst bubbles or build steam? Entrepreneurship education, entrepreneurial self-efficacy, and entrepreneurial intentions. Journal of Small Business Management, 53(4), 970-985.

Salvador, C. (2008). Impacto de la inteligencia emocional percibida en la autoeficacia emprendedora. Boletin de Psicologia, 92, 65-80.

Schjoedt, L. and Craig, J. (2017), Development and validation of a unidimensional domainspecific entrepreneurial self-efficacy scale, International Journal of Entrepreneurial Behavior \& Research, 23(1), 98-113. https://doi.org/10.1108/IJEBR-11-2015-0251.

Shane, S. (2009). Why encouraging more people to become entrepreneurs is bad public policy. Small business economics, 33(2), 141-149.

Shane, S. \& Venkataraman, S. (2000). The promise of entrepreneurship as a field of research. Academy of Management Review, 25(1), 217-226. 
Von Graevenitz, G., Harhoff, D. \& Weber, R. (2010). The effects of entrepreneurship education. Journal of Economic Behavior \& Organization, 76(1), 90-112.

Wennberg, K., Pathak, S. \& Autio, E. (2013). How culture moulds the effects of self-efficacy and fear of failure on entrepreneurship. Entrepreneurship and Regional Development, 25(9-10), 756-780.

Wilson, F., Kickul, J. \& Marlino, D. (2007). Gender, entrepreneurial self-efficacy, and entrepreneurial career intentions: Implications for entrepreneurship education. Entrepreneurship Theory and Practice, 31(3), 387-406.

Wilson, F., Kickul, J., Marlino, D., Barbosa, S. \& Griffiths, M. (2009). An analysis of the role of gender and self-efficacy in developing female entrepreneurial interest and behavior. Journal of Developmental Entrepreneurship, 14, 105-119.

Zhao, H., Seibert, S.E. \& Hills, G.E. (2005). The mediating role of self-efficacy in the development of entrepreneurial intentions. Journal of applied psychology, 90(6), 1265-1272. 